\title{
PENGARUH SIKAP, KONSEP DIRI, DAN KESADARAN METAKOGNITIF TERHADAP HASIL BELAJAR KIMIA PESERTA DIDIK KELAS XI MIA SMAN DI KECAMATAN UJUNG BULU KABUPATEN BULUKUMBA
}

\author{
Nuzul Kurnia Nurdianti Putri ${ }^{1}$, Muhammad Danial ${ }^{2}$, Nurdin Arsyad ${ }^{3}$ \\ ${ }^{1}$ Guru SMAN Kecamatan Ujung Bulu Kabupaten Bulukumba \\ ${ }^{2,3}$ Dosen Program Pascasarjana Universitas Negeri Makassar \\ Email: nuzul.kurnia42@gmail.com
}

\begin{abstract}
ABSTRAK
Rumusan masalah dalam penelitian ini adalah Bagaimana gambaran deskriptif sikap peserta didik pada mata pelajaran kimia, konsep diri, kesadaran metakognitif, dan hasil belajar kimia peserta didik kelas XI Mia SMAN di Kecamatan Ujung Bulu Kabupaten Bulukumba, apakah ada pengaruh sikap, konsep diri, dan kesadaran metakognitif, secara bersama-sama terhadap hasil belajar kimia peserta didik kelas, apakah ada pengaruh sikap terhadap hasil belajar kimia, apakah ada pengaruh konsep diri terhadap hasil belajar kimia, apakah ada pengaruh kesadaran metakognitif terhadap hasil belajar kimia, apakah ada interaksi sikap peserta didik pada mata pelajaran kimia dan konsep diri dalam mempengaruhi hasil belajar kimia, apakah ada interaksi konsep diri dan kesadaran metakognitif dalam mempengaruhi hasil belajar kimia peserta didik, apakah ada interaksi sikap peserta didik pada mata pelajaran kimia dan kesadaran metakognitif dalam mempengaruhi hasil belajar kimia peserta didik. Adapun tujuan dari penelitian ini sejalan dengan rumusan masalah Penelitian ini menggunakan pendekatan kuantitatif deskriptif dengan teknik pengumpulan data melalui penyebaran angket dan tes hasil belajar. Hasil penelitian menunjukkan bahwa Hasil analisis menunjukkan $\mathrm{p}$ - value < 0,05 yang artinya model layak digunakan. Model yang digunakan adalah $\mathrm{Y}=-75,003+$ $0,171 X_{1}+0,611 X_{2}+0,508 X_{3}+0,000 X_{1} X_{2}+0,000 X_{1} X_{3}-0,003 X_{2} X_{3}$. Sikap siswa, konsep diri, dan kesadaran metakognitif siswa berpengaruh signifikan dan positif terhadap hasil belajar kimia baik secara teoritis maupun secara empirik. Hasil uji parsial menunjukkan bahwa hasil interaksi antar variabel independent tidak berpengaruh signifikan terhadap hasil belajar kimia siswa, sehingga model terbaik yang dapat digunakan untuk menaksir hasil belajar kimia adalah model tanpa interaksi, yaitu: $\mathrm{Y}=-32,875+0,113 \mathrm{X}_{1}+0,217 \mathrm{X}_{2}+$ $0,200 \mathrm{X}_{3}$.
\end{abstract}

Kata Kunci: Sikap Siswa, Konsep Diri, Kesadaran metakognitif, Hasil Belajar.

\begin{abstract}
The formulation of the problem in this research is How to describe the descriptive attitude of learners on the subjects of chemistry, self-concept, metacognitive awareness, and the result of chemistry learners of class XI Mia SMAN in Ujung Bulu sub-district Bulukumba District. Is there influence attitude, Self-concept, and metacognitive awareness, together with the learning result of chemistry of class learners, is there influence of attitude toward result of chemistry study, is there influence of self-concept to result of chemistry study, is there influence of metacognitive awareness to result of chemistry study, is there interaction the attitude of learners on the subjects of chemistry and self-concept in influencing the learning outcomes of chemistry, is there interaction of self-concept and metacognitive awareness in influencing learners' chemistry learning outcomes, is there interaction of learners attitude on chemistry subjects and metacognitive awareness in influencing chemistry learning result learners. The purpose of this research is in line with the formulation of the problem. This research uses a descriptive quantitative approach with data collection techniques through questionnaires and
\end{abstract}


test results of learning. The results showed that the results of the analysis $\mathrm{P}-$ value $<0.05$ which means the model is worth used. The model is used $\mathrm{Y}=-75,003+0,171 \mathrm{X} 1+0,611$ $\mathrm{X} \neg 2+0,508 \mathrm{X} 3+0,000 \mathrm{X} 1 \mathrm{X} 2+0,000 \mathrm{X} 1 \mathrm{X} 3-0,003 \mathrm{X} 2 \mathrm{X} 3$. Student attitudes, self-concept, and metacognitive awareness of students have a significant and positive influence on the learning outcomes of chemistry both theoretically and empirically. The result of partial test shows that the interaction between the independent variables has no significant effect on the students chemistry learning result, so the best model that can be used to estimate the learning result of chemistry is the model without interaction, that is: $\mathrm{Y}=-32,875+0,113 \mathrm{X} 1+$ $0,217 \times 2+0,200 \times 3$.

Keywords: Student Attitude, Self Concept, Metacognitive Awareness, Learning Outcome

\section{PENDAHULUAN}

Peserta didik pada tingkat awal Sekolah Menengah Atas sering dihinggapi oleh kesan sulitnya pelajaran kimia, sehingga mempengaruhi prestasi belajar. Bagi sebagian peserta didik ilmu kimia adalah pelajaran yang membosankan karena mempelajari materi yang dianggap abstrak yaitu atom (partikel-partikel kecil) yang tidak dapat dilihat dan reaksi-reaksi kimia yang hanya bisa dilihat gejalanya sehingga peserta didik tidak tertarik untuk mempelajari kimia lebih lanjut. Penilaian ini akan berpengaruh pada perhatian dan minat belajarnya. Slameto (2003) menyatakan bahwa untuk menjamin hasil belajar yang baik, maka peserta didik harus memiliki sikap terhadap bahan yang dipelajarinya. Apabila bahan pelajaran tersebut tidak menjadi perhatian peserta didik, maka akan timbul kebosanan, sehingga berdampak pada keengganan untuk belajar. Kondisi ini dapat berpengaruh terhadap hasil belajar kimia nantinya. Berdasarkan hasil wawancara dengan beberapa guru kimia mengenai hasil belajar kimia peserta didik disalah satu sekolah yang akan menjadi sampel dalam penelitian ini bahwa masih banyak peserta didik yang hasil belajar kimianya di bawah nilai standar yang telah ditetapkan. Data nilai ulangan harian untuk dua tahun terakhir yaitu:

Opini negatif tentang kimia juga terlanjur berkembang dan melekat pada masyarakat khususnya peserta didik. Kimia dianggap sebagai pelajaran yang sulit, bahkan cenderung menjadi pelajaran yang menakutkan. Anggapan bahwa pelajaran kimia adalah pelajaran yang sulit dapat menimbulkan sikap yang berbeda untuk masing-masing peserta didik. Sikap yang timbul bisa positif, seperti menjadi bersemangat dalam mempelajari dan mengikuti proses pembelajaran kimia, karena merasa tertantang untuk menyelesaikan masalah-masalah kimia. Namun, bisa juga timbul sikap yang negatif, seperti menjadi malas untuk mempelajari kimia dan merasa tertekan atau mengalami gejala-gejala kecemasan dalam proses pembelajaran kimia.

Setiap peserta didik sudah pasti ingin mendapatkan hasil terbaik dalam setiap usaha yang dilakukan. Mereka ingin mendapat nilai yang baik dalam ujian sebagai cerminan keberhasilan dalam belajar. Sehingga tidak jarang peserta didik dirundung rasa cemas akan keberhasilannya dalam belajar. Tingkat kecemasan yang dirasakan peserta didik berbeda antara peserta didik satu dengan yang lainnya. Dampak dari kecemasan untuk masingmasing peserta didik juga berbeda. Kecemasan merupakan suatu keadaan emosional seseorang yang mempunyai ciri keterangsangan fisiologis, perasaan tegang, dan perasaan aprehensif bahwa sesuatu yang buruk akan terjadi (Nevid,2003). Kecemasan bisa berdampak baik ketika masih tergolong wajar dan terkendali, karena kinerja fisik dan intelektual siswa didorong dan diperkuat oleh kecemasan Durand dan Barlow (2006), 
Kecemasan seperti ini akan membuat siswa lebih siap menghadapi proses pembelajaran kimia, karena kecemasan mendorong siswa untuk lebih mempersiapkan diri. Sebaliknya, ketika tingkat kecemasan berlebihan dan tidak terkendali akan berdampak buruk bagi siswa. Kecemasan seperti ini membuat siswa sulit berkonsentrasi. Siswa dengan tingkat kecemasan yang berlebihan cenderung bersikap pesimis dalam menyelesaikan masalah kimia dan kurang termotivasi untuk mempelajarinya. Kecemasan yang berlebihan juga seringkali memposisikan kimia menjadi mata pelajaran yang ditakuti dan dihindari. Oleh karena itu, kecemasan yang berlebihan seperti ini dimungkinkan berdampak negatif pada hasil belajar kimia.

Kecemasan menghadapi situasi yang tidak pasti terhadap kemampuan dirinya dalam pembelajaran kimia dapat disebabkan oleh berbagai hal yang sangat bervariasi, misalnya konsep diri negatif terhadap kemampuan akademik, tipe kepribadian, dan tuntutan yang berlebihan dalam prestasi belajar kimia Amwalina (2006),. Ketika siswa mengkonsepkan dirinya tidak mampu atau tidak siap menghadapi tantangantantangan dalam proses belajar kimia, saat itulah timbul kekhawatiran dan kecemasan.

Kondisi lainnya adalah Konsep Diri. Fajar Fahrurrozi dalam penelitiannya pada mahasiswa Program Studi Ilmu Komunikasi mendapatkan bahwa mahasiswa dengan konsep diri positif mampu dalam pencapaian prestasi belajar yang tinggi. Konsep diri adalah pandangan dan sikap individu terhadap kemampuan dirinya sendiri yang mempunyai peran penting dalam menentukan dan mengarahkan seluruh tingkah laku individu. Peranan penting tersebut ditunjukkan dengan kenyataan bahwa setiap individu selalu berusaha untuk memperoleh keseimbangan dalam dirinya, selalu dihadapkan pada pengalaman hidup, dan selalu dipenuhi oleh kebutuhan untuk mencapai prestasi (Fahrurrozi:2007).

Selain dua kondisi diatas, kesadaran metakognitif juga diduga mempengaruhi hasil belajar kimia peserta didik. Mengukur kemajuan belajar peserta didik merupakan hal yang mendasar dalam proses pembelajaran. Namun, mendorong tumbuhnya kesadaran dan kebiasaan pada diri peserta didik untuk secara mandiri memantau dan mengevaluasi proses berpikir dan kemajuan belajarnya sendiri dipandang jauh lebih penting. Kesadaran metakognitif akan mendorong anak menjadi peka dan kritis terhadap kemajuan belajar yang telah dicapainya. Anak dengan kesadaran demikian akan senantiasa mengevaluasi diri mengenai kelebihan maupun keterbatasannya dalam mencapai suatu pemahaman tertentu.

Secara sederhana, kesadaran metakognitif merujuk pada kesadaran berpikir mengenai apa yang dipikirkan dan merefleksi atas tindakan-tindakan yang dilakukan (Baker dan Brown, 1985 dalam ali mahmudi, 2013). Seorang anak dengan kesadaran metakognitif bertanggung jawab terhadap proses belajar yang dilakukannya. Ia secara sadar mengetahui tujuan belajarnya, mengetahui cara atau proses berpikir untuk mencapainya, dan mengetahui pula cara mengetahui bahwa tujuan tersebut telah tercapai. Anak dengan kesadaran demikian juga akan menyadari apa yang telah diketahui, belum diketahui, dan perlu diketahui, serta mengetahui pula kelebihan maupun keterbatasannya.

Berdasarkan latar belakang masalah yang telah diuraikan di atas, maka rumusan masalah dalam penelitian ini adalah: (1) Bagaimana gambaran deskriptif sikap peserta didik pada mata pelajaran kimia, konsep diri, kesadaran metakognitif, dan hasil belajar kimia peserta didik kelas XI Mia SMAN di Kecamatan Ujung Bulu Kabupaten Bulukumba! (2) Apakah ada pengaruh sikap peserta didik pada mata pelajaran kimia, konsep diri, dan kesadaran metakognitif, secara bersama-sama terhadap hasil belajar kimia peserta didik kelas XI Mia SMAN di Kecamatan Ujung Bulu Kabupaten Bulukumba? (3) Apakah ada pengaruh sikap peserta didik pada mata pelajaran kimia terhadap hasil belajar kimia peserta didik kelas XI Mia SMAN di Kecamatan Ujung Bulu Kabupaten 
Bulukumba? (4) Apakah ada pengaruh konsep diri terhadap hasil belajar kimia peserta didik kelas XI Mia SMAN di Kecamatan Ujung Bulu Kabupaten Bulukumba? (5) Apakah ada pengaruh kesadaran metakognitif terhadap hasil belajar kimia peserta didik kelas XI Mia SMAN di Kecamatan Ujung Bulu Kabupaten Bulukumba? (6) Apakah ada interaksi sikap peserta didik pada mata pelajaran kimia dan konsep diri dalam mempengaruhi hasil belajar kimia peserta didik kelas XI Mia SMAN di Kecamatan Ujung Bulu Kabupaten Bulukumba? (7) Apakah ada interaksi konsep diri dan kesadaran metakognitif dalam mempengaruhi hasil belajar kimia peserta didik kelas XI Mia SMAN di Kecamatan Ujung Bulu Kabupaten Bulukumba? (8) Apakah ada interaksi sikap peserta didik pada mata pelajaran kimia dan kesadaran metakognitif dalam mempengaruhi hasil belajar kimia peserta didik kelas XI Mia SMAN di Kecamatan Ujung Bulu Kabupaten Bulukumba?

Berdasarkan rumusan masalah di atas, maka tujuan dari penelitian ini adalah: (1) Untuk mengetahui gambaran deskriptif sikap peserta didik pada mata pelajaran kimia, konsep diri, kesadaran metakognitif, dan hasil belajar kimia peserta didik kelas XI Mia SMAN di Kecamatan Ujung Bulu Kabupaten Bulukumba; (2) Untuk mengetahui ada tidaknya pengaruh sikap peserta didik pada mata pelajaran kimia, konsep diri, dan kesadaran metakognitif, secara bersama-sama terhadap hasil belajar kimia peserta didik kelas XI Mia SMAN di Kecamatan Ujung Bulu Kabupaten Bulukumba; (3) Untuk mengetahui ada tidaknya pengaruh sikap peserta didik pada mata pelajaran kimia terhadap hasil belajar kimia peserta didik kelas XI Mia SMAN di Kecamatan Ujung Bulu Kabupaten Bulukumba; (4) Untuk mengetahui ada tidaknya pengaruh konsep diri terhadap hasil belajar kimia peserta didik kelas XI Mia SMAN di Kecamatan Ujung Bulu Kabupaten Bulukumba; (5) Untuk mengetahui ada tidaknya pengaruh kesadaran metakognitif terhadap hasil belajar kimia peserta didik kelas XI Mia SMAN di Kecamatan Ujung Bulu Kabupaten Bulukumba; (6) Untuk mengetahui ada tidaknya interaksi sikap peserta didik pada mata pelajaran kimia dan konsep diri dalam mempengaruhi hasil belajar kimia peserta didik kelas XI Mia SMAN di Kecamatan Ujung Bulu Kabupaten Bulukumba; (7) Untuk mengetahui ada tidaknya interaksi konsep diri dan kesadaran metakognitif dalam mempengaruhi hasil belajar kimia peserta didik kelas XI Mia SMAN di Kecamatan Ujung Bulu Kabupaten Bulukumba; (8) Untuk mengetahui ada tidaknya interaksi sikap peserta didik pada mata pelajaran kimia dan kesadaran metakognitif dalam mempengaruhi hasil belajar kimia peserta didik kelas XI Mia SMAN di Kecamatan Ujung Bulu Kabupaten Bulukumba?

\section{METODE PENELITIAN}

Jenis penelitian ini adalah ex post facto causalitas. Penelitian ini bertujuan untuk menguji pengaruh variabel bebas dengan variabel terikat. Dengan demikian penelitian ini mencoba untuk melihat pengaruh terhadap variabel-variabel yang lainnya melalui pengujian hipotesa.

Populasi dan sampel penelitian sebagai berikut:

Tabel 3.1. Jumlah Populasi

\begin{tabular}{cccc}
\hline No & $\begin{array}{c}\text { Nama } \\
\text { Sekolah }\end{array}$ & Kelas & $\begin{array}{c}\text { Jumlah } \\
\text { Siswa }\end{array}$ \\
\hline \multirow{4}{*}{1} & & XI Mia 1 & 33 \\
& & XI Mia 2 & 32 \\
& SMAN 1 & XI Mia 3 & 32 \\
& Bulukumba & XI Mia 4 & 33 \\
& & XI Mia 5 & 32 \\
& & XI Mia 6 & 32 \\
& & XI Mia 7 & 35 \\
\multirow{4}{*}{2} & SMAN 8 & XI Mia 1 & 38 \\
& Bulukumba & XI Mia 2 & 37 \\
& & XI Mia 3 & 38 \\
& & XI Mia 4 & 37 \\
\hline \multirow{2}{*}{} & Jumlah & 12 & 38 \\
\hline
\end{tabular}


Adapun jumlah sampel penelitian yang terpilih yaitu 2 kelas dari SMAN 8 Bulukumba dan 3 kelas dari SMAN 1 Bulukumba dengan total sample 173 siswa.

Desain penelitian. Desain hubungan yang akan dianalisa dalam penelitian ini dapat dilihat pada Gambar 3.1.

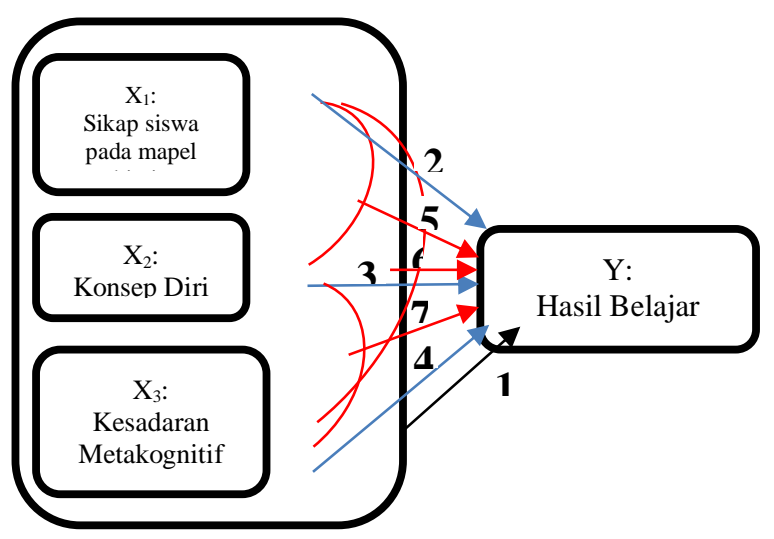

Gambar 3.1. Bagan Desain Penelitian

\section{Keterangan:}

$\mathrm{X}_{1}=$ Sikap peserta didik pada mapel kimia

$\mathrm{X}_{2}=$ Konsep Diri

$\mathrm{X}_{3}=$ Kesadaran Metakognisi

$1=$ Pengaruh $\mathrm{X}_{1}, \mathrm{X}_{2}$, dan $\mathrm{X}_{3}$ secara bersama-sama terhadap $\mathrm{Y}$

$2=$ Pengaruh $\mathrm{X}_{1}$ terhadap $\mathrm{Y}$

$3=$ Pengaruh $\mathrm{X}_{2}$ terhadap $\mathrm{Y}$

$4=$ Pengaruh $\mathrm{X}_{3}$ terhadap $\mathrm{Y}$

$5=$ Interaksi $X_{1}$ dan $X_{2}$ terhadap $Y$

$6=$ Interaksi $\mathrm{X}_{1}$ dan $\mathrm{X}_{3}$ terhadap $\mathrm{Y}$

$7=$ Interaksi $X_{2}$ dan $X_{3}$ terhadap $Y$

Teknik pengumpulan data untuk mendapatkan data yang diperlukan, maka teknik pengumpulan data yang dipergunakan dalam penelitian ini adalah:

Teknik Lapangan

Untuk memperoleh data dari lapangan ini penulis menggunakan teknik pengumpulan data sebagai berikut: (a) Angket; (b) Dokumentasi.

Metode dokumentasi dalam penelitian ini digunakan untuk mengetahui:

1) Nama dan jumlah peserta didik kelas XI Mia SMAN di Kecamatan Ujung Bulu Kabupaten Bulukumba
2) Nilai tes hasil belajar peserta didik kelas XI Mia SMAN di Kecamatan Ujung Bulu Kabupaten Bulukumba yang mengikuti pelajaran kimia.

Teknik analisis data

Untuk mengolah data dalam penelitian ini, penulis menggunakan langkah - langkah analisis data sebagai berikut: (1) Editing; (2) Scoring

Untuk mengitung perolehan hasil angket, penulis menetapkan penilaian jawaban siswa sebagai berikut :

Dan ada empat butir jawaban yang disediakan dengan ketentuan sebagai berikut:

Tabel 3.7. Bobot Skor untuk Pernyataan

\begin{tabular}{ccc}
\hline $\begin{array}{c}\text { Alternatif } \\
\text { jawaban }\end{array}$ & Positif & Nkor \\
\hline Sangat setuju & 4 & 1 \\
Setuju & 3 & 2 \\
Kurang & 2 & 3 \\
setuju & 1 & 4 \\
Tidak setuju & 1 & \\
\hline
\end{tabular}

Tabulating

Langkah selanjutnya adalah perhitungan terhadap data yang sudah discoring dengan menggunakan dua teknik analisis antara lain:

a. Teknik analisis deskriptif

b. Teknik analisis regresi multiple

\section{Instrumen penelitian}

Instrumen yang digunakan dalam penelitian ini berupa angket sikap siswa terhadap mapel kimia, angket konsep diri, dan angket kesadaran metakognisi.
a. Angket Konsep Diri
b. Angket Kesadaran Metakognisi
c. Angket Sikap Peserta Didik Pada Mapel Kimia

\section{HASIL DAN PEMBAHASAN \\ 1. Hasil Analisis Data Penelitian}

a. Analisis Data

Analisis data merupakan kegiatan yang dilakukan oleh peneliti dalam mengungkapkan makna dari data yang telah diperoleh dari proses penelitian yang telah 
dilakukan. Analisis data dalam penelitian ini adalah upaya menyelidiki secara mendalam tentang data yang berhasil diperoleh peneliti selama penelitian berlangsung, sehingga akan diketahui makna dan keadaan yang sebenarnya dari apa yang akan diteliti. Proses analisis data dilakukan sesuai dengan prosedur yang telah ditetapkan dalam bab sebelumnya.

Seleksi Data

Hasil kegiatan tersebut dapat dilihat dari Tabel 4.1.:

Tabel 4.1 Hasil Seleksi Data

\begin{tabular}{|c|c|c|c|c|c|}
\hline \multirow[b]{2}{*}{$\begin{array}{c}\text { Variabe } \\
1 \\
\text { peneliti } \\
\text { an }\end{array}$} & \multirow[b]{2}{*}{$\begin{array}{c}\text { Sumb } \\
\text { er } \\
\text { data }\end{array}$} & \multicolumn{4}{|c|}{ Jumlah angket } \\
\hline & & $\begin{array}{c}\text { Diseb } \\
\text { ar }\end{array}$ & $\begin{array}{c}\text { Terkum } \\
\text { pul }\end{array}$ & $\begin{array}{c}\text { Diol } \\
\text { ah }\end{array}$ & $\begin{array}{c}\text { Tida } \\
\mathrm{k} \\
\text { diola } \\
\mathrm{h} \\
\end{array}$ \\
\hline $\begin{array}{l}\text { Sikap } \\
\text { Siswa }\end{array}$ & $\begin{array}{c}\text { Angk } \\
\text { et }\end{array}$ & 173 & 173 & 173 & - \\
\hline $\begin{array}{c}\text { Konsep } \\
\text { Diri }\end{array}$ & $\begin{array}{c}\text { Angk } \\
\text { et }\end{array}$ & 173 & 173 & 173 & - \\
\hline $\begin{array}{c}\text { Kesadar } \\
\text { an }\end{array}$ & $\begin{array}{c}\text { Angk } \\
\text { et }\end{array}$ & 173 & 173 & 173 & - \\
\hline $\begin{array}{c}\text { Hasil } \\
\text { Belajar }\end{array}$ & THB & 173 & 173 & 173 & - \\
\hline
\end{tabular}

Sumber : Hasil Penelitian

Berdasarkan tabel 4.1 di atas dapat diketahui bahwa angket yang disebar dapat terkumpul kembali, sehingga dapat dilakukan kegiatan dalam tahapan berikutnya yaitu, tabulasi data.

b. Tabulasi Data

Kegiatan ini merupakan pemberian skor pada setiap alternatif jawaban yang diberikan oleh responden sesuai bobot yang telah ditetapkan. Setiap pernyataan dalam variabel Sikap Siswa, Konsep Diri, dan Kesadaran Metakognitif memiliki 4 kriteria jawaban dengan pemberian skor dimulai dari 1,2,3 dan 4, dengan ketentuan untuk pernyataan positif, yaitu : Skor $1=$ Tidak Setuju/Tidak Sesuai, Skor $2=$ Kurang Setuju/ Kurang Sesuai, Skor $3=$ Setuju/Sesuai, Skor $4=$ Sangat Setuju/Sangat Sesuai sedangkan untuk pernyataan negatif, yaitu : Skor $4=$ Tidak Setuju/Tidak Sesuai, Skor $3=$ Kurang Setuju/ Kurang Sesuai, Skor 2 =
Setuju/Sesuai, Skor $1=$ Sangat Setuju/Sangat Sesuai

Jumlah skor yang diperoleh responden merupakan skor mentah yang kemudian berfungsi sebagai data bagi pengolahan berikutnya.

c. Hasil Analisis Data

1) Hasil Analisis Deskriptif Variabel

Setelah pendeskripsian data, selanjutnya disajikan pada pengujian analisis, pengujian hipotesis, dan dilanjutkan dengan tafsiran hasil pengujian hipotesis.

a) Sikap Siswa

Distribusi frekuensi data tersebut dapat dilihat pada tabel berikut ini :

Tabel 4.2 Distribusi Frekuensi Skor Sikap Siswa

\begin{tabular}{|c|c|c|c|c|}
\hline No & $\begin{array}{c}\text { Kelas } \\
\text { interval }\end{array}$ & $\begin{array}{c}\text { Frekue } \\
\text { nsi }\end{array}$ & $\begin{array}{l}\text { Frekuen } \\
\text { si relatif }\end{array}$ & Kategori \\
\hline 1 & $71 \leq \mathrm{SS}<91$ & 5 & $4 \%$ & Negatif \\
\hline 2 & $\begin{array}{c}91 \leq \mathrm{SS} \\
<111\end{array}$ & 52 & $37 \%$ & $\begin{array}{c}\text { Cenderung } \\
\text { negatif }\end{array}$ \\
\hline 3 & $\begin{array}{c}111 \leq \mathrm{SS} \\
<131\end{array}$ & 76 & $53 \%$ & $\begin{array}{c}\text { Cenderung } \\
\text { positif }\end{array}$ \\
\hline 4 & $\begin{array}{c}131 \leq \mathrm{SS} \\
<151\end{array}$ & 9 & $6 \%$ & Positif \\
\hline & Total & 142 & $100 \%$ & \\
\hline
\end{tabular}

Data terkumpul menunjukkan bahwa rentangan bagi skor total Sikap Siswa adalah skor minimum 71 dan skor maksimum 151. Untuk perhitungan lengkapnya dapat dilihat pada lampiran. Berdasarkan tabel diatas menunjukkan frekuensi tertinggi terdapat pada kelas interval no 3 yang memiliki rentang 111 - 131 dengan jumlah sebanyak 76 siswa atau sekitar $53 \%$ sedangkan frekuensi terendah sekitar $4 \%$ atau sebanyak 5 siswa.

Tabel 4.3 Analisis Deskriptif Sikap Siswa terhadap mata pelajaran kimia

\begin{tabular}{clc}
\hline No & \multicolumn{2}{c}{ Analisis Deskriptif Sikap } \\
\hline 1 & N Statistik & 142 \\
2 & Range Statistik & 67 \\
3 & Min Statistik & 72 \\
4 & Max Statistik & 139 \\
5 & Sum & 16156 \\
6 & Mean & 113,77 \\
7 & Std Deviasi & 11,676 \\
8 & Variance & 136,332 \\
9 & Skewness & $-0,659$ \\
10 & Kurtosis & 1,235 \\
\hline
\end{tabular}


Berdasarkan data diatas menunjukkan nilai rata-rata 113,77 dengan standar deviasi 11, 676 dan variansi 136,332 dari skor ideal 148, skor minimum 72 dan skor maksimum 139 menjelaskan bahwa siswa SMAN di Kecamatan Ujung Bulu memiliki sikap pada kategori Cenderung Positif terhadap mata pelajaran kimia.

Secara keseluruhan, berdasarkan data tersebut dapat disimpulkan bahwa siswa yang memiliki sikap terhadap mata pelajaran kimia pada kategori cenderung positif, diindikasikan memiliki ketertarikan yang lebihh baik untuk mengikuti dan mempelajari pelajaran kimia yang telah diajarkan oleh guru dengan baik dan sungguh-sungguh, sehingga hal tersebut dapat menjadi salah satu factor yang mendukung dalam meningkatkan hasil belajar kimia siswa

b) Konsep Diri

Distribusi frekuensi data tersebut dapat dilihat pada Tabel 4.4:

Tabel 4.4 Distribusi Frekuensi Skor Konsep Diri

\begin{tabular}{|c|c|c|c|c|}
\hline No & $\begin{array}{l}\text { Kelas } \\
\text { interval }\end{array}$ & $\begin{array}{c}\text { Frekuen } \\
\text { si }\end{array}$ & $\begin{array}{c}\text { Frekuen } \\
\text { si } \\
\text { relative }\end{array}$ & Kategori \\
\hline 1 & $\begin{array}{c}55 \leq \mathrm{KD}< \\
67\end{array}$ & 2 & $2 \%$ & Negatif \\
\hline 2 & $\begin{array}{c}67 \leq \mathrm{KD}< \\
79\end{array}$ & 1 & $0 \%$ & $\begin{array}{c}\text { Cenderung } \\
\text { negatif }\end{array}$ \\
\hline 3 & $\begin{array}{c}79 \leq \mathrm{KD}< \\
91\end{array}$ & 123 & $87 \%$ & \multirow{2}{*}{$\begin{array}{c}\text { Cenderung } \\
\text { positif } \\
\text { Positif }\end{array}$} \\
\hline 4 & $\begin{array}{c}91 \leq \mathrm{KD}< \\
103\end{array}$ & 16 & $11 \%$ & \\
\hline & Total & 142 & $100 \%$ & \\
\hline
\end{tabular}

Data terkumpul menunjukkan bahwa rentangan bagi skor total Konsep Diri adalah skor minimum 55 dan skor maksimum 103. Untuk perhitungan lengkapnya dapat dilihat pada lampiran. Berdasarkan tabel diatas menunjukkan frekuensi tertinggi terdapat pada kelas interval no 3 yang memiliki rentang $79-91$ dengan jumlah sebanyak 123 siswa atau sekitar $87 \%$ sedangkan frekuensi terendah sekitar $0 \%$ atau sebanyak 1 siswa.

Tabel 4.5 Analisis Deskriptif Sikap Siswa terhadap mata pelajaran kimia

\begin{tabular}{cr}
\hline No & Analisis Deskriptif Sikap \\
\hline 1 & N Statistik
\end{tabular}

$\begin{array}{clc}2 & \text { Range Statistik } & 36 \\ 3 & \text { Min Statistik } & 58 \\ 4 & \text { Max Statistik } & 94 \\ 5 & \text { Sum } & 12135 \\ 6 & \text { Mean } & 85,46 \\ 7 & \text { Std Deviasi } & 4,894 \\ 8 & \text { Variance } & 23,952 \\ 9 & \text { Skewness } & -1,995 \\ 10 & \text { Kurtosis } & 9,397\end{array}$

Berdasarkan data diatas menunjukkan nilai rata-rata 85,46 dengan standar deviasi 4,894 dan variansi 23,952 dari skor ideal 100, skor minimum 58 dan skor maksimum 94 menjelaskan bahwa siswa SMAN di Kecamatan Ujung Bulu memiliki Konsep Diri pada kategori Cenderung Positif terhadap mata pelajaran kimia.

Secara keseluruhan, berdasarkan data tersebut dapat disimpulkan bahwa siswa yang memiliki Konsep Diri pada kategori cenderung positif, diindikasikan memiliki ketertarikan dan semangat yang lebih baik untuk belajar dan memami konsep kimia sehingga meningkatkan hasil belajar kimianya.

c) Kesadaran Metakognitif

Distribusi frekuensi data tersebut dapat dilihat pada Tabel 4.6:

Tabel 4.6 Distribusi Frekuensi Skor Kesadaran Metakognitif

\begin{tabular}{|c|c|c|c|c|}
\hline $\begin{array}{c}\mathrm{N} \\
\mathrm{o}\end{array}$ & $\begin{array}{c}\text { Kelas } \\
\text { interval }\end{array}$ & Frekuensi & $\begin{array}{c}\text { Frekuen } \\
\text { si } \\
\text { relative }\end{array}$ & Kategori \\
\hline 1 & $\begin{array}{c}102 \leq \\
\text { KM }< \\
132\end{array}$ & 11 & $8 \%$ & Rendah \\
\hline 2 & $\begin{array}{c}132 \leq \\
\mathrm{KM}< \\
162\end{array}$ & 85 & $60 \%$ & $\begin{array}{c}\text { Cenderung } \\
\text { Rendah }\end{array}$ \\
\hline 3 & $\begin{array}{c}162 \leq \\
\mathrm{KM}< \\
193\end{array}$ & 44 & $31 \%$ & $\begin{array}{c}\text { Cenderung } \\
\text { Tinggi }\end{array}$ \\
\hline 4 & $\begin{array}{c}193 \leq \\
\mathrm{KM}< \\
208\end{array}$ & 2 & $1 \%$ & Tinggi \\
\hline & Total & 142 & $100 \%$ & \\
\hline
\end{tabular}

Data terkumpul menunjukkan bahwa rentangan bagi skor total Kesadaran Metakognitif adalah skor minimum 102 dan skor maksimum 208. Untuk perhitungan lengkapnya dapat dilihat pada lampiran. Berdasarkan tabel diatas menunjukkan frekuensi tertinggi terdapat pada kelas 
interval no 2 yang memiliki rentang 132 162 dengan jumlah sebanyak 85 siswa atau sekitar $60 \%$ sedangkan frekuensi terendah sekitar $1 \%$ atau sebanyak 2 siswa.

Tabel 4.7 Analisis Deskriptif Kesadaran Metakognitif

\begin{tabular}{clc}
\hline No & \multicolumn{2}{c}{ Analisis Deskriptif Sikap } \\
\hline 1 & N Statistik & 142 \\
2 & Range Statistik & 92 \\
3 & Min Statistik & 104 \\
4 & Max Statistik & 196 \\
5 & Sum & 22044 \\
6 & Mean & 155,24 \\
7 & Std Deviasi & 16,857 \\
8 & Variance & 284,169 \\
9 & Skewness & $-0,045$ \\
10 & Kurtosis & 0,385 \\
\hline
\end{tabular}

Berdasarkan data diatas menunjukkan nilai rata-rata 155,24 dengan standar deviasi 16,857 dan variansi 284,169 dari skor ideal 208, skor minimum 104 dan skor maksimum 196 menjelaskan bahwa siswa SMAN di Kecamatan Ujung Bulu memiliki Kesadaran Metakognitif pada kategori Cenderung Rendah.

Secara keseluruhan, berdasarkan data tersebut dapat disimpulkan bahwa siswa yang memiliki tingkat kesadaran metakognitif pada kategori cenderung rendah, diindikasikan kurang memiliki kemampuan dalam mengetahui apa saja yang mereka pahami dan yang tidak mereka pahami dalam pembelajaran kimia serta diindikasikan juga siswa akan agak sulit untuk memahami konsep kimia, sehingga kemungkinan hasil belajarnya tidak akan meningkat.

d) Hasil Belajar

Tes hasil belajar adalah tes yang digunaan untuk mengukur kemampuan peserta didik (Trianto, 2011 dalam biologimu, 2015).

Tabel 4.8 Kategori Hasil Belajar

\begin{tabular}{cc}
\hline Interval Skor/Nilai & Kategori \\
\hline $85-100$ & Sangat tinggi \\
$65-84$ & Tinggi \\
$55-64$ & Cukup \\
$35-54$ & Rendah \\
$0-34$ & Sangat rendah \\
\hline
\end{tabular}

Sumber : Depdikbud, 2009

Sedangkan kategori nilai berdasarkan permendikbud no. 81 a tahun 2013

Tabel 4.9 Kategori Hasil Belajar

\begin{tabular}{cccc}
\hline \multicolumn{2}{c}{$\begin{array}{c}\text { Konversi Nilai } \\
\text { Akhir }\end{array}$} & & \\
\cline { 1 - 2 } $\begin{array}{c}\text { Skala 0- } \\
100\end{array}$ & $\begin{array}{c}\text { Skala 1- } \\
\text { Predikat }\end{array}$ & Keterangan \\
\cline { 1 - 2 } $86-100$ & 4 & A & \multirow{2}{*}{ SB } \\
$81-85$ & 3.66 & A- & \\
$76-80$ & 3.33 & B + & \\
$71-75$ & 3 & B & B \\
$66-70$ & 2.66 & B & \\
$61-65$ & 2.33 & C+ & \\
$56-60$ & 2 & C & C \\
$51-55$ & 1.66 & C- & \\
$46-50$ & 1.33 & D+ & K \\
$0-45$ & 1 & D & \\
\hline
\end{tabular}

Data Hasil Belajar Peserta Didik (Y) merupakan hasil tes tertulis yang dilakukan oleh peneliti. Penskoran tanpa koreksi, yaitu penskoran dengan cara setiap butir soal yang dijawab benar mendapat nilai satu (tergantung dari bobot butir soal), sehingga jumlah skor yang diperoleh peserta didik adalah dengan menghitung banyaknya butir soal yang dijawab benar. Rumusnya sebagai berikut.

$$
\text { Skor }=\frac{B}{N} \times 100(\text { skala } 0-100)
$$

$\mathrm{B}=$ banyaknya butir yang dijawab benar $\mathrm{N}=$ adalah banyaknya butir soal

Tabel 4.10 Distribusi frekuensi hasil belajar kimia siswa

\begin{tabular}{ccccc}
\hline No & Skor & Frekuensi & $\%$ & Kategori \\
\hline 1 & $\begin{array}{c}1 \leq \mathrm{HB}< \\
50\end{array}$ & 9 & $6 \%$ & Kurang \\
& $\begin{array}{c}51 \leq \mathrm{HB} \\
<65\end{array}$ & 42 & $30 \%$ & Cukup \\
& $\begin{array}{c}66 \leq \mathrm{HB} \\
<80\end{array}$ & 44 & $31 \%$ & Baik \\
& $\begin{array}{c}81 \leq \mathrm{HB} \\
<\end{array}$ & 47 & $33 \%$ & $\begin{array}{c}\text { Sangat } \\
\text { Baik }\end{array}$ \\
\hline & Total & 142 & $100 \%$ & \\
\hline
\end{tabular}

Data terkumpul menunjukkan bahwa rentangan bagi skor total Hasil Belajar Peserta Didik adalah skor minimum 1 dan skor maksimum 100. Untuk perhitungan lengkapnya dapat dilihat pada lampiran.

Tabel 4.10 menunjukkan bahwa sebanyak 9 siswa (6\%) mempunyai hasil belajar kimia kurang, 42 siswa (30\%) mempunyai hasil belajar kimia yang cukup, 44 siswa (31\%) mempunyai hasil belajar kimia yang baik dan 47 siswa (33\%) 
mempunyai hasil belajar kimia yang sangat baik.

Tabel 4.11 Analisis Deskriptif Hasil Belajar Kimia Siswa

\begin{tabular}{clc}
\hline No & \multicolumn{2}{c}{ Analisis Deskriptif Sikap } \\
\hline 1 & N Statistik & 142 \\
2 & Range Statistik & 28 \\
3 & Min Statistik & 11 \\
4 & Max Statistik & 39 \\
5 & Sum & 4190 \\
6 & Mean & 29,51 \\
7 & Std Deviasi & 6,074 \\
8 & Variance & 36,890 \\
9 & Skewness & $-0,192$ \\
10 & Kurtosis & $-0,396$ \\
\hline & Berdasarkan data diatas menunjukkan
\end{tabular}

nilai rata-rata 29,51 dengan standar deviasi 6,074 dan variansi 36,890 dari skor ideal 40, skor minimum 11 dan skor maksimum 39 menjelaskan bahwa siswa SMAN di Kecamatan Ujung Bulu memiliki hasil belajar kimia yang baik.

2) Pengujian dan Persyaratan Analisis

Uji persyaratan dalam penelitian ini menggunakan uji asumsi klasik yaitu uji multikolinieritas, uji heteroskedasitas, dan uji normalitas.

1) Uji multikolinieritas

Hasil pengujian pada penelitian ini dengan menggunakan program SPSS v24 diperoleh output (terlampir) nilai VIF lebih kecil dari 10 sehingga dapat dikatakan kalau semua variabel bebas dari gejala multikolinieritas. Jadi data dalam penelitian ini layak untuk diuji menggunakan model uji regresi berganda.

2) Uji heteroskedasitas

Hasil output SPSS v24 (terlampir) dalam penelitian ini diperoleh interpretasi (pada baris terakhir atau kolom terakhir).

Tabel $4.12 \quad$ Interpretasi uji heteroskedastisitas

\begin{tabular}{|c|c|c|c|}
\hline $\begin{array}{c}\text { Variabel } \\
\text { Bebas }\end{array}$ & $\mathrm{r}$ & Sig & Ket \\
\hline $\begin{array}{l}\text { Sikap Siswa } \\
\text { (X1) }\end{array}$ & 0,049 & 0,283 & Homoskedastisitas \\
\hline $\begin{array}{l}\text { Konsep Diri } \\
(\mathrm{X} 2)\end{array}$ & 0,014 & 0,432 & Homoskedastisitas \\
\hline $\begin{array}{l}\text { Kesadaran } \\
\text { Metakognitif } \\
\text { (X3) }\end{array}$ & $0, \overline{100}$ & 0,118 & Homoskedastisitas \\
\hline
\end{tabular}

Dari data tabel diatas menunjukkan bahwa semua variabel memiliki nilai signifikansi yang lebih besar dari 0,05 sehingga dapat dikatakan bahwa variabel yang diuji tidak mengandung heteroskedastisitas atau homoskedastisitas. Artinya tidak ada korelasi antara besarnya data dengan residual sehingga bila data diperbesar tidak menyebabkan residual (kesalahan) semakin besar pula. Jadi data dalam penelitian ini layak untuk diuji menggunakan model uji regresi berganda.

3) Uji Normalitas

Data (terlampir) pada penelitian ini berdistribusi normal sesuai dengan hasil uji Kolmogorov-Smirnov yang menunjukkan bahwa $p$ value $=0,200>\alpha$. Jadi data dalam penelitian ini layak untuk diuji lebih lanjut menggunakan uji regresi berganda.

4) Hasil Analisis Regresi Multiple

Hasil analisis regresi multiple menghasilkan nilai $\mathrm{R}=0,766$ yang menjelaskan bahwa terdapat hubungan yang sangat kuat antara sikap siswa, konsep diri, dan kesadaran metakognitif terhadap hasil belajar kimia. Jadi semakin tinggi sikap, konsep diri, dan kesadaran metakognitif siswa maka akan semakin tinggi pula hasil belajar kimianya.

Nilai Adjusted R square sebesar 0,578, hal ini menunjukkan bahwa ketiga variabel independent berpengaruh $57,8 \%$ terhadap hasil belajar kimia dan sisanya dipengaruhi oleh variabel lain yang tidak diteliti.

Hasil ANOVA menunjukkan p-value $0,000<$ dari $\alpha$ yang artinya model layak digunakan. Sehingga persamaan regresinya adalah

$$
\mathrm{Y}=-75,003+0,171 \mathrm{X}_{1}+0,611 \mathrm{X}-
$$
${ }_{2}+0,508 \mathrm{X}_{3}+0,000 \mathrm{X}_{1} \mathrm{X}_{2}+0,000 \mathrm{X}_{1} \mathrm{X}_{3}$

$0,003 \mathrm{X}_{2} \mathrm{X}_{3}$

e) Pengujian Hipotesis Penelitian

1) Pengujian secara parsial (Individu)

Untuk menguji hipotesis secara parsial digunakan uji t yaitu untuk menguji secara parsial variabel bebas terhadap variabel terikat. Hasil perhitungan dijelaskan sebagai berikut: 
a) Hipotesis 2 (Pengaruh sikap peserta didik pada mata pelajaran kimia terhadap hasil belajar kimia).

$\mathrm{H}_{0}: \beta_{1}=0 \mathrm{Vs} \mathrm{H}_{1}: \beta_{1} \neq 0$

$\mathrm{H}_{0}$ : Tidak ada pengaruh sikap peserta didik pada mata pelajaran kimia, terhadap hasil belajar kimia

$\mathrm{H}_{1}$ : Ada pengaruh positif sikap peserta didik pada mata pelajaran kimia terhadap hasil belajar kimia

Tabel 4.13 Hasil Uji t (parsial) untuk Sikap Siswa

\begin{tabular}{|c|c|c|c|c|c|c|}
\hline \multicolumn{7}{|c|}{ Coefficients $^{\mathrm{a}}$} \\
\hline \multirow[t]{2}{*}{ Model } & \multicolumn{2}{|c|}{$\begin{array}{l}\text { Unstandardi } \\
\text { zed } \\
\text { Coefficients }\end{array}$} & \multirow{2}{*}{$\begin{array}{c}\begin{array}{c}\text { Standard } \\
\text { ized }\end{array} \\
\begin{array}{c}\text { Coeffici } \\
\text { ents }\end{array} \\
\text { Beta }\end{array}$} & \multirow[t]{2}{*}{$\mathrm{t}$} & \multirow[t]{2}{*}{$\begin{array}{l}\mathrm{Si} \\
\mathrm{g} .\end{array}$} & $\begin{array}{c}\text { Correlat } \\
\text { ions }\end{array}$ \\
\hline & B & $\begin{array}{c}\text { Std. } \\
\text { Error }\end{array}$ & & & & $\begin{array}{l}\text { Zero- } \\
\text { order }\end{array}$ \\
\hline $\begin{array}{r}\text { (Const } \\
1 \quad \text { ant) }\end{array}$ & $\begin{array}{c}- \\
1.5 \\
26 \\
\end{array}$ & 4.281 & & $\begin{array}{l}- \\
.35 \\
6\end{array}$ & $\begin{array}{l}.7 \\
22\end{array}$ & \\
\hline SIKAP & $\begin{array}{c}.27 \\
3 \\
\end{array}$ & .037 & .524 & $\begin{array}{l}7.2 \\
86 \\
\end{array}$ & $\begin{array}{c}.0 \\
00 \\
\end{array}$ & .524 \\
\hline
\end{tabular}

Uji t terhadap variabel Sikap (X1) didapatkan $t_{\text {hitung }}$ sebesar 7,286 dengan signifikansi $t$ sebesar 0,000 . Karena $t_{\text {hitung }}$ lebih besar $t_{\text {tabel }}(7,286>1.65597)$ atau signifikansi t lebih kecil dari 5\% $(0,000<$ 0,05), maka secara parsial $\mathrm{H}_{0}$ ditolak dan $\mathrm{H}_{1}$ diterima yang berarti bahwa variabel Sikap Siswa (X1) berpengaruh signifikan terhadap variabel Hasil Belajar Kimia (Y).

b) Hipotesis 3 (Pengaruh konsep diri terhadap hasil belajar kimia).

$\mathrm{H}_{0}: \beta_{2}=0 \mathrm{Vs} \mathrm{H}_{1}: \beta_{2} \neq 0$

$\mathrm{H}_{0}$ :Tidak ada pengaruh konsep diri terhadap hasil belajar kimia

$\mathrm{H}_{1}$ :Ada pengaruh konsep diri terhadap hasil belajar kimia.

Tabel 4.14 Hasil Uji t (parsial) untuk Konsep Diri

\begin{tabular}{|c|c|c|c|c|c|c|}
\hline \multicolumn{7}{|c|}{ Coefficients $^{\mathrm{a}}$} \\
\hline \multirow[t]{2}{*}{ Model } & \multicolumn{2}{|c|}{$\begin{array}{l}\text { Unstandard } \\
\text { ized } \\
\text { Coefficient } \\
\text { s } \\
\end{array}$} & \multirow{2}{*}{$\begin{array}{c}\begin{array}{c}\text { Standard } \\
\text { ized } \\
\text { Coefficie } \\
\text { nts }\end{array} \\
\text { Beta }\end{array}$} & \multirow[t]{2}{*}{$\mathrm{t}$} & \multirow{2}{*}{$\begin{array}{l}\mathrm{Si} \\
\mathrm{g} .\end{array}$} & $\begin{array}{c}\text { Correlati } \\
\text { ons }\end{array}$ \\
\hline & B & $\begin{array}{l}\text { Std. } \\
\text { Err } \\
\text { or } \\
\end{array}$ & & & & $\begin{array}{l}\text { Zero- } \\
\text { order }\end{array}$ \\
\hline $\begin{array}{r}\text { (Const } \\
1 \quad \text { ant) }\end{array}$ & $\begin{array}{c}- \\
18,6 \\
22 \\
\end{array}$ & $\begin{array}{c}8,0 \\
00\end{array}$ & & $\begin{array}{c}- \\
2,3 \\
28 \\
\end{array}$ & $\begin{array}{l}.0 \\
21\end{array}$ & \\
\hline $\begin{array}{c}\text { KONS } \\
\text { EP }\end{array}$ & .563 & $\begin{array}{c}.09 \\
3\end{array}$ & .454 & $\begin{array}{l}6,0 \\
26\end{array}$ & $\begin{array}{l}.0 \\
00\end{array}$ & .454 \\
\hline
\end{tabular}

Uji t terhadap variabel Konsep Diri (X2) didapatkan thitung sebesar 6,026 dengan signifikansi t sebesar 0,000. Karena $t_{\text {hitung }}$ lebih besar $t_{\text {tabel }}(6,026>1.65597)$ atau signifikansi t lebih kecil dari 5\% (0,000 < 0,05), maka secara parsial $\mathrm{H}_{0}$ ditolak dan $\mathrm{H}_{1}$ diterima yang berarti bahwa variabel Konsep Diri (X2) berpengaruh signifikan terhadap variabel Hasil Belajar Kimia (Y).

c) Hipotesis 4 (Pengaruh kesadaran metakognitif terhadap hasil belajar kimia).

$\mathrm{H}_{0}: \beta_{3}=0 \mathrm{Vs} \mathrm{H}_{1}: \beta_{3} \neq 0$

$\mathrm{H}_{0}$ :Tidak ada pengaruh kesadaran metakognitif terhadap hasil belajar kimia

$\mathrm{H}_{1}$ :Ada pengaruh kesadaran metakognitif terhadap hasil belajar kimia

Tabel 4.15 Hasil Uji t (parsial) untuk Kesadaran Metakognitif

\begin{tabular}{|c|c|c|c|c|c|c|}
\hline \multicolumn{7}{|c|}{ Coefficients $^{\mathrm{a}}$} \\
\hline \multirow{2}{*}{ Model } & \multicolumn{2}{|c|}{$\begin{array}{c}\text { Unstandar } \\
\text { dized } \\
\text { Coefficient } \\
\mathrm{s} \\
\end{array}$} & \multirow{2}{*}{$\begin{array}{c}\begin{array}{c}\text { Standard } \\
\text { ized } \\
\text { Coefficie } \\
\text { nts }\end{array} \\
\\
\text { Beta }\end{array}$} & \multirow{2}{*}{$\mathrm{t}$} & \multirow{2}{*}{$\begin{array}{l}\mathrm{Si} \\
\mathrm{g} .\end{array}$} & $\begin{array}{l}\text { Correlat } \\
\text { ions }\end{array}$ \\
\hline & B & $\begin{array}{l}\text { Std. } \\
\text { Err } \\
\text { or }\end{array}$ & & & & $\begin{array}{l}\text { Zero- } \\
\text { order }\end{array}$ \\
\hline $\begin{array}{c}\text { (Const } \\
1 \quad \text { ant) }\end{array}$ & $\begin{array}{c}- \\
10,2 \\
67\end{array}$ & $\begin{array}{c}3,3 \\
43\end{array}$ & & $\begin{array}{c}- \\
3,07 \\
1\end{array}$ & $\begin{array}{l}.0 \\
03\end{array}$ & \\
\hline $\begin{array}{c}\text { KESADA } \\
\text { RAN }\end{array}$ & .256 & $\begin{array}{c}.02 \\
1\end{array}$ & .711 & $\begin{array}{c}11,9 \\
67\end{array}$ & $\begin{array}{l}.0 \\
00\end{array}$ & .711 \\
\hline
\end{tabular}

Uji $t$ terhadap variabel Kesadaran Metakognitif (X3) didapatkan thitung sebesar 11,967 dengan signifikansi t sebesar 0,000. Karena $t_{\text {hitung }}$ lebih besar $t_{\text {tabel }}(11,967>$ 1.65597) atau signifikansi t lebih kecil dari $5 \%(0,000<0,05)$, maka secara parsial $\mathrm{H}_{0}$ ditolak dan $\mathrm{H}_{1}$ diterima yang berarti bahwa variabel Kesadaran Metakognitif (X3) berpengaruh signifikan terhadap variabel Hasil Belajar Kimia (Y).

2) Pengujian secara simultan (Bersama)

Uji hipotesis secara simultan yaitu untuk menguji pengaruh secara bersamasama variabel bebas terhadap variabel terikat digunakan uji F. Dari hasil perhitungan didapatkan nilai $F_{\text {hitung }}$ sebesar $65.445(\mathrm{p}-$ value $=0,000)$. Jadi $F_{\text {hitung }}>F_{\text {tabel }}(65.445>$ 2.67 ) atau Sig $F<5 \%(0,000<0,05)$. Artinya bahwa secara bersama-sama 
variabel bebas yang terdiri dari variabel Sikap Siswa (X1), Konsep Diri (X2), Kesadaran Metakognitif (X3), berpengaruh signifikan terhadap variabel Hasil Belajar Kimia Siswa (Y).

Dari nilai Adjusted $\mathrm{R}$ Square menunjukkan nilai sebesar 0,578 atau 57,8\%. Artinya bahwa variabel Y dipengaruhi sebesar 57,8\% oleh Sikap Siswa (X1), Konsep Diri (X2), Kesadaran Metakognitif (X3), sedangkan sisanya $42,2 \%$ dipengaruhi oleh variabel lain di luar 3 variabel bebas yang diteliti tersebut. Adapun model persamaan regresi linier berganda yang diperoleh adalah sebagai berikut:

$\mathrm{Y}=-32,875+0,113 \mathrm{X}_{1}+0,217 \mathrm{X}_{2}+0,200 \mathrm{X}_{3}$

Tabel 4.16 Hasil Uji F (Simultan) Bersama

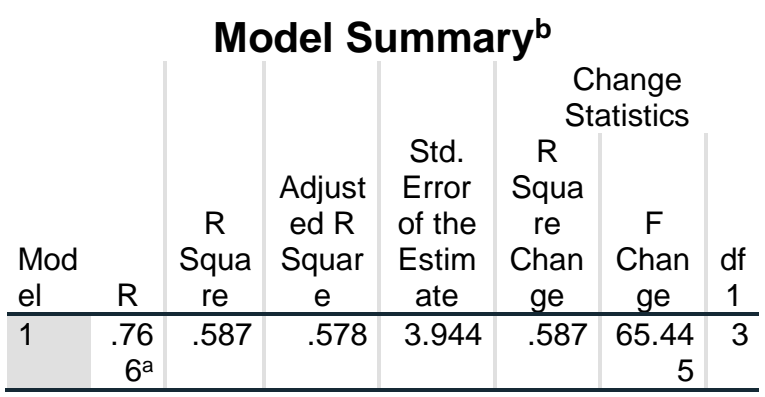

\begin{tabular}{|c|c|c|}
\hline \multirow[b]{2}{*}{ Model } & \multicolumn{2}{|c|}{$\begin{array}{c}\text { Model Summary } \\
\text { Change Statist }\end{array}$} \\
\hline & $\mathrm{df2}$ & Sig. F Change \\
\hline 1 & 138 & .00 \\
\hline
\end{tabular}

a. Predictors: (Constant), KESADARAN, KONSEP, SIKAP

b. Dependent Variable: HASILBELAJAR

\begin{tabular}{|c|c|c|c|c|c|}
\hline \multirow[b]{3}{*}{ Model } & \multicolumn{3}{|c|}{ Coefficients $^{a}$} & \multirow[b]{3}{*}{$\mathrm{T}$} & \multirow[b]{3}{*}{ Sig } \\
\hline & \multicolumn{2}{|c|}{$\begin{array}{l}\text { Unstandardi } \\
\text { zed } \\
\text { Coefficients }\end{array}$} & \multirow{2}{*}{$\begin{array}{c}\text { Standardiz } \\
\text { ed } \\
\text { Coefficient } \\
\text { s } \\
\text { Beta }\end{array}$} & & \\
\hline & & $\begin{array}{l}\text { Std. } \\
\text { Error }\end{array}$ & & & \\
\hline 1 (Constant) & - & 5.96 & & - & .00 \\
\hline & $\begin{array}{r}32.87 \\
5\end{array}$ & 2 & & $\begin{array}{r}5.51 \\
4\end{array}$ & 0 \\
\hline SIKAP & .113 & .033 & .217 & $\begin{array}{r}3.43 \\
7\end{array}$ & $\begin{array}{r}.00 \\
1\end{array}$ \\
\hline KONSEP & .217 & .075 & .175 & $\begin{array}{r}2.88 \\
2\end{array}$ & $\begin{array}{r}.00 \\
5\end{array}$ \\
\hline $\begin{array}{l}\text { KESADAR } \\
\text { AN }\end{array}$ & .200 & .022 & .555 & $\begin{array}{r}8.88 \\
2\end{array}$ & $\begin{array}{r}.00 \\
0\end{array}$ \\
\hline
\end{tabular}

Untuk menguji variabel dominan, terlebih dahulu diketahui kontribusi masingmasing variabel bebas yang diuji terhadap variabel terikat. Kontribusi masing-masing variabel diketahui dari koefisien determinasi regresi sederhana terhadap variabel terikat atau diketahui dari kuadrat korelasi sederhana variabel bebas dan terikat. Dari tabel di bawah diketahui bahwa variabel yang paling dominan pengaruhnya adalah variabel Kesadaran Metakognitif (X3) yaitu memiliki kontribusi sebesar 50,6\%.

Tabel 4.17 Kontribusi Variabel yang Dominan

\begin{tabular}{lcccc}
\hline \multicolumn{2}{c}{ Variabel } & $\mathrm{r}$ & $\mathrm{R}^{2}$ & $\begin{array}{c}\text { Kontribusi } \\
(\%)\end{array}$ \\
\hline $\begin{array}{l}\text { Sikap } \\
\begin{array}{l}\text { (X1) } \\
\text { Konsep Siswa }\end{array}\end{array}$ & 0,524 & 0,275 & $27,5 \%$ \\
$\begin{array}{l}\text { (X2) Diri } \\
\text { Kesadaran }\end{array}$ & 0,454 & 0,206 & $20,6 \%$ \\
$\begin{array}{l}\text { Metakognitif } \\
\text { (X3) }\end{array}$ & 0,711 & 0,506 & $50,6 \%$ \\
\hline
\end{tabular}

3) Uji Interaksi

Uji Interaksi yaitu aplikasi dari regresi linear berganda dimana dalam persamaannya mengandung unsur interaksi (perkalian dua/lebih variabel independen).

\section{Model Summary}

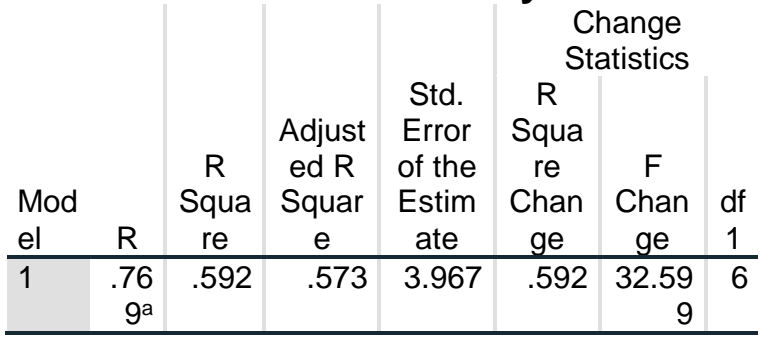

\section{Model Summary}

\begin{tabular}{lcr} 
Model & df2 & $\begin{array}{r}\text { Change Statistics } \\
\text { Sig. F Change }\end{array}$ \\
\hline 1 & 135 & .000 \\
\hline a. Predictors: (Constant), X2X3, SIKAP, KONSEP, \\
KESADARAN, X1X3, X1X2
\end{tabular}
KESADARAN, X1X3, X1X2

\begin{tabular}{|c|c|c|c|c|c|}
\hline \multicolumn{6}{|c|}{ ANOVA $^{a}$} \\
\hline Model & $\begin{array}{l}\text { Sum of } \\
\text { Squares }\end{array}$ & $\mathrm{df}$ & $\begin{array}{l}\text { Mean } \\
\text { Square }\end{array}$ & $\mathrm{F}$ & Sig. \\
\hline $\begin{array}{l}1 \text { Regressio } \\
n\end{array}$ & $\begin{array}{r}3077.41 \\
6\end{array}$ & 6 & $\begin{array}{r}512.90 \\
3\end{array}$ & $\begin{array}{r}32.59 \\
9\end{array}$ & .000 \\
\hline Residual & $\begin{array}{r}2124.07 \\
7 \\
\end{array}$ & $\begin{array}{r}13 \\
5 \\
\end{array}$ & 15.734 & & \\
\hline Total & $\begin{array}{r}5201.49 \\
3\end{array}$ & $\begin{array}{r}14 \\
1\end{array}$ & & & \\
\hline
\end{tabular}




\begin{tabular}{|c|c|c|c|c|c|}
\hline & $\begin{array}{r}\text { Coe } \\
\text { Unstan } \\
\text { ec } \\
\text { Coeffic }\end{array}$ & $\begin{array}{l}\text { fficie } \\
\text { dardiz } \\
\text { ients }\end{array}$ & $\begin{array}{l}\text { ts }^{\mathbf{a}} \\
\text { Standardi } \\
\text { zed } \\
\text { Coefficien } \\
\text { ts }\end{array}$ & & \\
\hline Model & B & $\begin{array}{l}\text { Std. } \\
\text { Error }\end{array}$ & Beta & $\mathrm{T}$ & Sig \\
\hline 1 (Constant) & 75.003 & $\begin{array}{r}45.5 \\
30\end{array}$ & & $\begin{array}{r}- \\
1.6 \\
47\end{array}$ & $\begin{array}{r}.10 \\
2\end{array}$ \\
\hline SIKAP & .171 & .555 & .328 & $\begin{array}{r}.30 \\
7\end{array}$ & $\begin{array}{r}.75 \\
9\end{array}$ \\
\hline KONSEP & .611 & .586 & .493 & $\begin{array}{r}1.0 \\
44\end{array}$ & $\begin{array}{r}.29 \\
9\end{array}$ \\
\hline $\begin{array}{l}\text { KESADAR } \\
\text { AN }\end{array}$ & .508 & .326 & 1.410 & $\begin{array}{r}1.5 \\
60\end{array}$ & $\begin{array}{r}.12 \\
1\end{array}$ \\
\hline $\mathrm{X} 1 \mathrm{X} 2$ & .000 & .006 & .038 & $\begin{array}{r}.03 \\
0 \\
\end{array}$ & $\begin{array}{r}.97 \\
6 \\
\end{array}$ \\
\hline $\mathrm{X} 1 \mathrm{X} 3$ & .000 & .002 & -.237 & $\begin{array}{r}- \\
.22 \\
4\end{array}$ & $\begin{array}{r}.82 \\
3\end{array}$ \\
\hline X2X3 & -.003 & .004 & -.892 & $\begin{array}{r}- \\
.82 \\
5\end{array}$ & $\begin{array}{r}.41 \\
1\end{array}$ \\
\hline
\end{tabular}

Coefficients $^{a}$

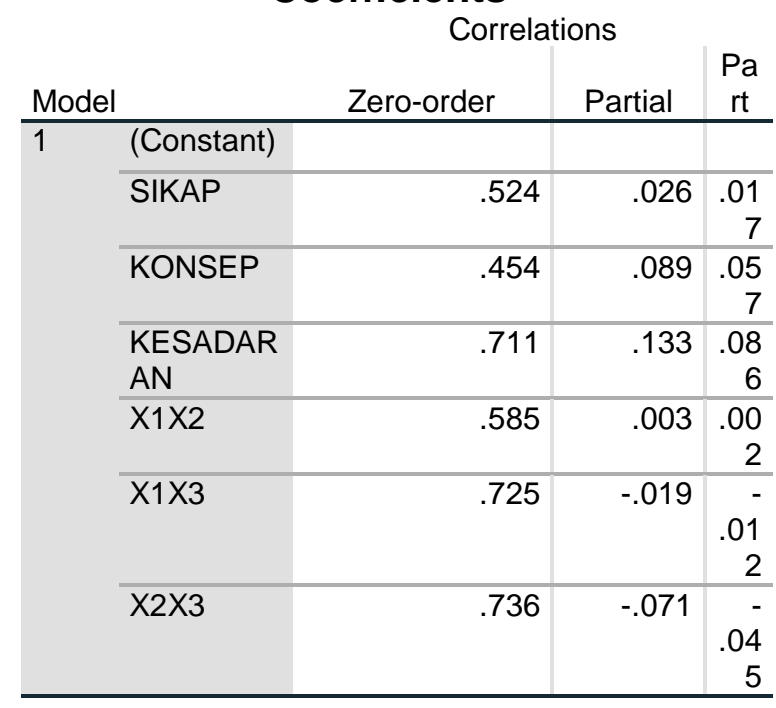

Dari nilai Adjusted $\mathrm{R}$ Square menunjukkan nilai sebesar 0,573 atau 57,3\%. Artinya bahwa variabel Y dipengaruhi sebesar 57,3\% oleh Interaksi ketiga variabel bebas Sikap Siswa (X1), Konsep Diri (X2), Kesadaran Metakognitif (X3), sedangkan sisanya 42,7\% dipengaruhi oleh variabel lain di luar 3 variabel bebas yang diteliti tersebut. Adapun model persamaan regresi linier berganda yang diperoleh adalah sebagai berikut: $\mathrm{Y}=-75,003+0,171 \mathrm{X}_{1}+0,611 \mathrm{X}-$ ${ }_{2}+0,508 \mathrm{X}_{3}+0,000 \mathrm{X}_{1} \mathrm{X}_{2}+0,000 \mathrm{X}_{1} \mathrm{X}_{3}-0,003$ $\mathrm{X}_{2} \mathrm{X}_{3}$
Model ini secara simultan terbukti signifikan karena nilai $\mathrm{p}$ - value yaitu 0,000 $<$ dari $\alpha(0,05)$ maka artinya bahwa secara bersama-sama interaksi variabel bebas yang terdiri dari variabel Sikap Siswa (X1), Konsep Diri (X2), Kesadaran Metakognitif (X3), berpengaruh signifikan terhadap variabel Hasil Belajar Kimia Siswa (Y).

Untuk menguji variabel dominan, terlebih dahulu diketahui kontribusi masingmasing interaksi variabel bebas yang diuji terhadap variabel terikat. Kontribusi masingmasing interaksi variabel diketahui dari koefisien determinasi regresi sederhana terhadap variabel terikat atau diketahui dari kuadrat korelasi sederhana variabel bebas dan terikat. Dari tabel di bawah diketahui bahwa interaksi variabel yang paling dominan pengaruhnya adalah interaksi variabel X5 (X1X3) yaitu memiliki kontribusi sebesar $57 \%$.

Tabel 4.18 Kontribusi Variabel yang Dominan

\begin{tabular}{lccc}
\hline \multicolumn{1}{c}{ Variabel } & $\mathrm{r}$ & $\mathrm{R}^{2}$ & $\begin{array}{c}\text { Kontribusi } \\
(\%)\end{array}$ \\
\hline $\begin{array}{l}\text { X4 (Interaksi } \\
\text { X1X2) }\end{array}$ & 0,595 & 0,355 & $35,5 \%$ \\
$\begin{array}{l}\text { X5 (Interaksi } \\
\text { X1X3) }\end{array}$ & 0,755 & 0,570 & $57 \%$ \\
$\begin{array}{l}\text { X6 (Interaksi } \\
\text { X2X3) }\end{array}$ & 0,745 & 0,555 & $55,5 \%$ \\
\hline
\end{tabular}

\section{Pembahasan Hasil Penelitian}

a) Karakteristik Variabel

Berdasarkan hasil penelitian diperoleh bahwa nilai rata-rata sikap peserta didik pada mata pelajaran kimia sebesar 113,77. Hal ini menunjukkan bahwa secara umum sikap siswa pada mata pelajaran kimia di SMAN yang berada di Kecamatan ujung bulu Kabupaten Bulukumba tergolong pada kategori cenderung positif. Dari segi konsep diri siswa kelas XI SMAN di Kecamatan Ujung Bulu Kabupaten Bulukumba memperoleh nilai rata-rata 85,46. Ini menuunjukkan bahwa secara umum konsep diri siswa itu tergolong pada kategori cenderung positif.

b) Pengaruh variabel bebas terhadap variabel terikat 
1) Pengaruh sikap siswa, konsep diri, dan kesadaran metakognitif, secara bersama-sama terhadap hasil belajar kimia

Berdasarkan hasil penelitian diperoleh $\mathrm{R}$ Square sikap siswa, konsep diri dan kesadaran metakognitif terhadap hasil belajar siswa sebesar 0,587 dengan nilai $\mathrm{p}=$ $0,000<\alpha(0,05)$. Ini menunjukkan bahwa sikap siswa, konsep diri, dan kesadaran metakognitif siswa berpengaruh signifikan positif terhadap hasil belajar kimia. Hal ini dapat diartikan bahwa jika seorang siswa memiliki sikap yang baik dengan konsep diri dan kesadaran metakognitif yang tinggi maka hasil belajar kimia siswa itu juga akan meningkat.

Hasil pengujian terhadap hipotesis pertama yang menyatakan sikap, konsep diri dan kesadaran metakognitif secara bersamasama berpengaruh signifikan terhadap hasil belajar kimia, diterima. Hal ini berarti terjadi kesesuaian antara hipotesis dengan data yang ada.

2) Pengaruh sikap siswa pada mapel kimia terhadap hasil belajar

Berdasarkan hasil penelitian diperoleh R Square sikap siswa terhadap hasil belajar siswa sebesar 0,275 dengan nilai $\mathrm{p}=0,000<$ $\alpha(0,05)$. Ini menunjukkan bahwa sikap siswa, berpengaruh signifikan positif terhadap hasil belajar kimia. Hal ini dapat diartikan bahwa jika seorang siswa memiliki sikap yang baik terhadap mata pelajaran kimia maka hasil belajar kimia siswa itu juga akan meningkat.

Hasil pengujian terhadap hipotesis kedua yang menyatakan sikap, berpengaruh signifikan terhadap hasil belajar kimia, diterima. Hal ini berarti terjadi kesesuaian antara hipotesis dengan data yang ada sekaligus memperkuat pandangan teori sikap, sebagai konsep yang memperhatikan cara seorang individu berpikir, bertindak, dan bertingkah laku. Sikap mempunyai pengaruh yang serius untuk siswa, guru, kelompok social yang berhubungan dengan individu siswa dan seluruh sistem di sekolah (Yara;2009,).
Menurut Ngalim Purwanto (2007), sikap adalah suatu cara bereaksi terhadap suatu perangsang. Dalam pengertian ini sikap merupakan kecenderungan seseorang untuk bereaksi dengan cara tertentu terhadap suatu obyek atau situasi yang dihadapi sehingga sikap dapat bersifat positif dan ada pula yang bersifat negatif. Sikap positif adalah kecenderungan tindakan untuk mendekati, menyenangi, mengharapkan obyek-obyek tertentu. Sedangkan sikap negatif adalah kecenderungan untuk menjauhi, menghindari, membenci, tidak menyukai obyek-obyek tertentu.

3) Pengaruh konsep diri terhadap hasil belajar

Berdasarkan hasil penelitian diperoleh $\mathrm{R}$ Square konsep diri terhadap hasil belajar siswa sebesar 0,454 dengan nilai $\mathrm{p}=0,000<$ $\alpha(0,05)$. Ini menunjukkan bahwa konsep diri, berpengaruh signifikan positif terhadap hasil belajar kimia. Hal ini dapat diartikan bahwa jika seorang siswa memiliki konsep diri yang baik terhadap mata pelajaran kimia maka hasil belajar kimia siswa itu juga akan meningkat.

Hasil penelitian ini sejalan dengan penelitian Sagita Suryade (2014), dengan hasil penelitian menunjukkan bahwa terdapat pengaruh yang signifikan antara konsep diri terhadap prestasi belajar siswa di Sekolah Menengah Atas Negeri 1 Ujungbatu, dengan kontribusi konsep diri terhadap prestasi belajar adalah $0,587 \mathrm{x}$ $100 \%=58,7 \%$ dan selebihnya dipengaruhi oleh variabel lain. Di mana ro (observasi) $=$ 0,766 , lebih besar dari rt (tabel) pada taraf signifikan $5 \%$ maupun $1 \%$ yaitu $0,217<$ $0,766>0,283$, ini berarti Ha diterima dan Ho ditolak.

4) Pengaruh positif kesadaran metakognitif terhadap hasil belajar

Berdasarkan hasil penelitian diperoleh $\mathrm{R}$ Square kesadaran metakognitif terhadap hasil belajar siswa sebesar 0,506 dengan nilai $\mathrm{p}=0,000<\alpha(0,05)$. Ini menunjukkan bahwa kesadaran metakognitif, berpengaruh signifikan positif terhadap hasil belajar kimia. Hal ini dapat diartikan bahwa jika seorang siswa memiliki kesadaran 
metakognitif yang tinggi maka hasil belajar kimia siswa itu juga akan meningkat.

Hasil pengujian terhadap hipotesis keempat yang menyatakan kesadaran metakognitif, berpengaruh signifikan terhadap hasil belajar kimia, diterima. Hal ini berarti terjadi kesesuaian antara hipotesis dengan data yang ada sekaligus memperkuat pandangan teori kesadaran metakognitif.

Hasil penelitian ini bermakna bahwa metakognisi siswa mampu memberi kontribusi terhadap hasil belajar kimia siswa, oleh karena itu untuk meningkatkan hasil belajar siswa, maka metakognisi siswa perlu dikembangkan melalui kegiatan belajar dan pembelajaran adalah sebagai berikut membantu peserta didik dalam mengembangkan strategi belajar dengan mendorong pembelajar untuk memonitor proses belajar dan berpikirnya, membimbing pembelajar dalam mengembangkan strategistrategi belajar yang efektif, meminta pembelajar untuk membuat prediksi tentang informasi yang akan muncul atau disajikan berikutnya berdasarkan apa yang mereka telah baca atau pelajari, membimbing pembelajar untuk mengembangkan kebiasaan bertanya, dan menunjukkan kepada pembelajar bagaimana teknik mentransfer pengetahuan, sikap-sikap, nilainilai, keterampilan-keterampilan dari suatu situasi ke situasi yang lain. Selain itu, metakognisi siswa dapat ditingkatkan melalui pengembangan kebiasaan untuk berpikir positif, kebiasaan untuk bertanya, dan kebiasaan mengelola diri sendiri.

5) Interaksi sikap dan konsep diri dalam mempengaruhi hasil belajar

Berdasarkan hasil penelitian diperoleh bahwa tabel coefficient menunjukkan bahwa $p$-value $=0,976>\alpha=0,05$. Berdasarkan hal tersebut, maka keputusan uji adalah menerima $\mathrm{H}_{0}$. Jadi tidak ada interaksi antara sikap dan konsep diri siswa yang berpengaruh terhadap hasil belajar kimia siswa kelas XI SMAN di Kecamatan Ujung bulu Kabupaten Bulukumba.

6) Interaksi sikap dan kesadaran metakognitif dalam mempengaruhi hasil belajar
Berdasarkan hasil penelitian diperoleh bahwa tabel coefficient menunjukkan bahwa $p$-value $=0,823>\alpha=0,05$. Berdasarkan hal tersebut, maka keputusan uji adalah menerima $\mathrm{H}_{0}$. Jadi tidak ada interaksi antara sikap dan kesadaran metakognitif siswa yang berpengaruh terhadap hasil belajar kimia siswa kelas XI SMAN di Kecamatan Ujung bulu Kabupaten Bulukumba.

7) Interaksi konsep diri dan kesadaran metakognitif dalam mempengaruhi hasil belajar

Berdasarkan hasil penelitian diperoleh bahwa tabel coefficient menunjukkan bahwa $\mathrm{p}$-value $=0,411>\alpha=0,05$. Berdasarkan hal tersebut, maka keputusan uji adalah menerima $\mathrm{H}_{0}$. Jadi tidak ada interaksi antara konsep diri siswa dan kesadaran metakognitif yang berpengaruh terhadap hasil belajar kimia siswa kelas XI SMAN di Kecamatan Ujung bulu Kabupaten Bulukumba.

Berdasarkan pada hasil uji hipotesis yang menunjukkan bahwa interaksi antara variabel bebas dalam mempengaruhi hasil belajar kimia siswa tidak signifikan, maka dapat disimpulkan bahwa model terbaik untuk menaksir hasil belajar kimia siswa adalah model tanpa interaksi yaitu: $\mathrm{Y}=$ $32,875+0,113 X_{1}+0,217 X_{2}+0,200 X_{3}$.

Hasil analisis tanpa interaksi menghasilkan nilai $\mathrm{p}-$ value $<0,05$ yang sama pada model dengan melibatkan interaksi. Masing - masing variabel, yaitu sikap siswa, konsep diri dan kesadaran metakognitif berpengaruh secara signifikan dan positif terhadap hasil belajar kimia. Hal tersebut menjelaskan bahwa dalam menaksir hasil belajar kimia siswa kelas XI SMAN di Kecamatan Ujung Bulu Kabupaten Bulukumba, yang terbaik adalah hanya dengan melibatkan ketiga variabel secara independent dan tidak perlu melibatkan variabel lainnya termasuk interaksi antar variabel independentnya.

c) Keterbatasan Penelitian

kelemahan dalam pelaksanaan pengumpulan data sulit dihindari, antara lain karena siswa yang terpilih sebagai responden merasa gugup karena peneliti 
adalah tentor ditempat siswa belajar. Sehingga dalam menjawab pertanyaan atau pernyataan kadang dijawab secara tergesahgesah. Meskipun sebelumnya diberi pengarahan baik dari segi tujuan penelitian ini maupun bimbingan dalam pengisian instrumen.

Kelemahan dari segi instrumen penelitian, meskipun peneliti secara jeli dalam merumuskan instrumen untuk menghimpun informasi mengenai dimensi dan indikator variabel, dibuat dan dikembangkan sedemikian rupa sehingga kekhawatiwan akan terjadi tumpang tindih antara variabel instrumen sedapat mungkin dihindari. Kendatipun telah dirumuskan dalam bentuk formulasi yang bervariasi berdasarkan teori yang digunakan, tapi tidak tertutup kemungkinan adanya kekurangan dalam penyusunan dan pengembangan setiap butir. Oleh karena itu dalam pengolahan data, ada beberapa responden yang dihilangkan karena merupakan Outliers (pencilan data) adalah data observasi yang muncul dengan nilai-nilai ekstrim baik secara univariat maupun multivariat. Data ekstrim tersebut muncul karena berbagai kemungkinan misalnya karena keadaan yang benar-benar khusus, seperti pandangan responden terhadap sesuatu yang menyimpang, karena ada sesuatu alasan yang tidak diketahui penyebabnya oleh peneliti, muncul dalam range nilai yang ada, tetapi bila dikombinasi dengan variabel lain menjadi ekstrim (disebut multi variat outliers).

\section{KESIMPULAN}

Bedasarkan analisis data dengan perhitungan statistik dan hasil pengujian hipotesis serta dari pembahasan, maka hasil penelitian ini disimpulkan sebagai berikut:

1. Hasil analisis menunjukkan $\mathrm{p}$ - value < 0,05 yang artinya model layak digunakan. Model yang digunakan adalah

$$
\begin{gathered}
Y=-75,003+0,171 X_{1}+0,611 X_{2}+ \\
0,508 X_{3}+0,000 X_{1} X_{2}+0,000 X_{1} X_{3}- \\
0,003 X_{2} X_{3}
\end{gathered}
$$

2. Sikap siswa, konsep diri, dan kesadaran metakognitif siswa berpengaruh signifikan dan positif terhadap hasil belajar kimia baik secara teoritis maupun secara empirik

3. Sikap siswa berpengaruh signifikan dan positif terhadap hasil belajar kimia baik secara teoritis maupun secara teoritis maupun empirik

4. Konsep diri siswa berpengaruh signifikan dan positif terhadap hasil belajar kimia baik secara teoritis maupun secara teoritis maupun empirik

5. Kesadaran metakognitif siswa berpengaruh signifikan dan positif terhadap hasil belajar kimia baik secara teoritis maupun secara teoritis maupun empirik

6. Tidak ada interaksi sikap dan konsep diri dalam mempengaruhi hasil belajar kimia peserta didik kelas XI Mia SMAN di Kecamatan Ujung Bulu Kabupaten Bulukumba

7. Tidak ada interaksi sikap dan kesadaran metakognitif dalam mempengaruhi hasil belajar kimia peserta didik kelas XI Mia SMAN di Kecamatan Ujung Bulu Kabupaten Bulukumba

8. Tidak ada interaksi konsep diri dan kesadaran metakognitif dalam mempengaruhi hasil belajar kimia peserta didik kelas XI Mia SMAN di Kecamatan Ujung Bulu Kabupaten Bulukumba

9. Hasil uji parsial menunjukkan bahwa hasil interaksi antar variabel independent tidak berpengaruh signifikan terhadap hasil belajar kimia siswa, sehingga model terbaik yang dapat digunakan untuk menaksir hasil belajar kimia adalah model tanpa interaksi, yaitu:

$\mathrm{Y}=-32,875+0,113 \mathrm{X}_{1}+0,217 \mathrm{X}_{2}+$ $0,200 X_{3}$.

\section{DAFTAR PUSTAKA}

A.M. Sardiman. 2011. Interaksi dan MotivasiBelajarMengajar. Jakarta: Rajawali. 
Abu Ahmadi, 2004. Psikologi Belajar. Jakarta: Rineka Cipta.

Alex Sobur. 2016. Psikologi Umum (revisi). Bandung: PustakaSetia.

Amwalina. 2006. Hubungan Antara Konsep Diri Akademik Dengan Kecemasan Menghadapi Ujian Nasional. Skripsi: Universitas Islam Indonesia.

http://psychology.uii.ac.id/images/s tories/jadwal_kuliah/naskahpublikasi- 00320050.pdf. Tanggal akses: 2 Oktober 2016.

Anas Sudijono. (2008). Pengantar Evaluasi Pendidikan. Jakarta: PT. Rajagrafindo Persada.

Anis fauziana, 2008. Identifikasi karakteristik metakognisi siswa dalam memecahkan masalahmatematika dikelas VIII-F SMP N 1 Gresik, Skripsi.Tidak dipublikasikan. Surabaya:UNESA

Arikunto, Suharsimi. 2006. Prosedur Penelitian. Jakarta: PT RinekaCipta.

Azwar, Saifuddin. 1995. Sikap Manusia, Teori dan Pengukurannya. Yogyakarta : Liberty.

Curtis, Karena M. 2006. Improving Student Attitudes: A Study of A Mathematics Curriculum Innovation. $\quad \mathrm{http} / / / \mathrm{krex} . \mathrm{k}-$ state.edu/dspace/bitstream/2097/15 1/1/Karena Curtis2006.pdf. Diakses 2 Oktober 2016.

Darsono, max dkk. 2001. Belajar dan Pembelajaran. Semarang: IKIP Semarang Press. Depdiknas. 2004. Kurikulum 2004 SMP Pedoman Khusus Pengembangan Sistem Penilaian Berbasis Kompetensi Mata Pelajaran Sains. Jakarta: Depdiknas.

Desmita. 2009. Psikologi Perkembangan Peserta Didik. Bandung: PT Remaja Rosdakarya.

Durand, V. Mark \& Barlow, David H. 2006. Inti sari Psikologi Abnormal. Yogyakarta: Pustaka Belajar.
E.P. Hutabaret, 1998. Cara Belajar.Jakarta: PT BPK GunungMulia,

Elida Prayitno. 1990. Perkembangan Peserta Didik (Remaja) Padang: FIP IKIP Padang

Fahrurrozi, F. 2007. Pengaruh Konsep Diri dalam Pencapaian Prestasi Belajar. Fakultas Ilmu Komunikasi Universitas Padjadjaran, Jurusan Manajemen Komunikasi.

Hanafiah, Nanang \&CucuSuhana. 2010. Konsep Strategi Pembelajaran. Bandung: Refika Aditama.

Hardjana, Agus M. 1994. Kiat Sukses di PerguruanTinggi. Yogyakarta: Kanisius.

http://www.belajarbagus.net/2015/04/faktoryang-mempengaruhi-belajar.html. tanggal akses 17 oktober 2016

IbnuHajar, 1996. Dasar-Dasar Metodologi Kuantitatif Dalam Pendidikan, Jakarta PT. Raja GrafindoPersada,

Ismaimuza, D.2010. Pengaruh pembelajaran berbasis masalah dengan strategi konflik kognitif terhadap Kemampuan berpikir kritis matematis dan sikap siswa SMP. Jurnal pendidikan matematika volume 4.no.1.

Keliat, Budi Anna, Dkk. 2005 .Proses Keperawatan Kesehatan Jiwa Edisi 2. Jakarta: EGC

Khadijah tabrani. 2012. Sikap Peserta Didik. http://khadijahtabrani.blogspot.co.i d/2012/04/sikap-peserta-didik.html Tanggal akses 2 Oktober 2016

Kulm, Gerald. 1980. "Research on Mathematic Attitude". Dalam Richard J. Shumway. Research in Mathematics Education. Reston VA: The National Council of Teachers of Mathematics Inc.

Lexi J Moloeng,1990. Metode Penelitian Kualitatif, Bandung :Tarsito

M. NgalimPurwanto. 2002. Psikologi Pendidikan. Bandung: Remaja Rosdakarya. Makalah disajikan pada seminar nasional pendidikan matematika di IAIN sunan ampel Surabaya tanggal 24 mei 2008, 
Mardalis.1995. Metode Penelitian suatu pendekatan proposal, Jakarta: Bumi Aksara

Mahasiswa.mipastkipllg.com/repository/Arti kel20Ikeb\%20Trymas\%20Ayuland a.pdf. tanggal akses 17 oktober 2016 